Editorial

\title{
Ecoregional and Archetypical Considerations for National Responses to Food Security under Climate Change
}

\author{
Yu-Pin Lin ${ }^{1, *(\mathbb{D})}$, Josef Settele ${ }^{2}$ and Joy R. Petway ${ }^{1}$ \\ 1 Department of Bioenvironmental Systems Engineering, National Taiwan University, No. 1, Sec. 4, \\ Roosevelt Rd., Taipei 10617, Taiwan; d05622007@ntu.edu.tw \\ 2 Department of Community Ecology, Helmholtz-Centre for Environmental Research-UFZ \\ Theodor-Lieser-Str. 4, 06120 Halle, Germany; josef.settele@ufz.de \\ * Correspondence: yplin@ntu.edu.tw; Tel.: +886-2-33663467
}

Received: 12 February 2018; Accepted: 22 February 2018; Published: 25 February 2018

Determining national responsibility for ecological sustainability based on resource use within an 'ecoregion' (defined by World Wildlife Fund) or 'archetype' [1] may provide needed insight into global food security issues since conservation can increase food security and maintain global biodiversity [2]. While climate change causes ecoregions to shift [3] and creates variation among biodiversity quality and ecosystem health within ecoregions, developed countries intensively import food from lesser-developed countries [4] further diminishing the ecoregional environmental health of those countries. Moreover, climate variability and change from either natural causes or human activities may impact agricultural products at ecoregional and international levels [5] by stressing terrestrial ecosystems and affecting atmospheric composition so that agricultural productivity in different ecoregions vary [5,6]. Yet, even though countries fall within a geographically distinct ecoregion or archetype with specific production capacities, and while the complexity of economic interdependencies has further redefined the limits of a country's borders, food security issues are typically only addressed at the local or country-level rather than at the ecoregional or archetype level. Understanding a country's potential to exhaust an ecoregion's or archetype's resource-specific ecosystem functions will help in effective management and governance to sustain these functions, which also requires maintaining biodiversity quality and ecosystem health. Insights derived from these kinds of ecological considerations' national responses under climate change can influence the way we approach global food production and global food security.

Conflicts of Interest: The authors declare no conflict of interest.

\section{References}

1. Václavík, T.; Langerwisch, F.; Cotter, M.; Fick, J.; Häuser, I.; Hotes, S.; Kamp, J.; Settele, J.; Spangenberg, J.H.; Seppelt, R. Investigating potential transferability of place-based research in land system science. Environ. Res. Lett. 2016, 11, 095002. [CrossRef]

2. Tilman, D.; Clark, M.; Williams, D.R.; Kimmel, K.; Polasky, S.; Packer, C. Future threats to biodiversity and pathways to their prevention. Nature 2017, 546, 73-81. [CrossRef] [PubMed]

3. Yin, Y.; Tang, Q.; Wang, L.; Liu, X. Risk and contributing factors of ecosystem shifts over naturally vegetated land under climate change in China. Sci. Rep. 2016, 6, 20905. [CrossRef] [PubMed]

4. Reynolds, M.P.; Braun, H.J.; Cavalieri, A.J.; Chapotin, S.; Davies, W.J.; Ellul, P.; Feuillet, C.; Govaerts, B.; Kropff, M.J.; Lucas, H.; et al. Improving global integration of crop research. Science 2017, 357, 359-360. [CrossRef] [PubMed]

5. Wheeler, T.; Von Braun, J. Climate change impacts on global food security. Science 2013, 341, 508-513. [CrossRef] [PubMed] 
6. Bonan, G.B.; Doney, S.C. Climate, ecosystems, and planetary futures: The challenge to predict life in Earth system models. Science 2018, 359. [CrossRef] [PubMed]

(C) 2018 by the authors. Licensee MDPI, Basel, Switzerland. This article is an open access article distributed under the terms and conditions of the Creative Commons Attribution (CC BY) license (http://creativecommons.org/licenses/by/4.0/). 